\title{
Surfaces
}

\section{Ludwig Pfeiffer's "Culture and the Humanities: Symptomatologies, Mostly Historical, Mainly German"} Roundtable Discussion

\author{
Hazard Adams, Ernst Behler, Hendrik Birus, Jacques Derrida, Wolfgang Iser, \\ Murray Krieger, Hillis Miller, Ludwig Pfeiffer, Bill Readings, Ching-hsien Wang \\ et Pauline $\mathrm{Yu}$
}

Volume 6, 1996

DISCUSSIONS DU PREMIER CONGRÈS INTERNATIONAL SUR LE DISCOURS HUMANISTE

DISCUSSIONS FROM THE FIRST INTERNATIONAL CONFERENCE ON HUMANISTIC DISCOURSE

URI : https://id.erudit.org/iderudit/1064842ar

DOI : https://doi.org/10.7202/1064842ar

Aller au sommaire du numéro

Éditeur(s)

Les Presses de l’Université de Montréal

ISSN

1188-2492 (imprimé)

1200-5320 (numérique)

Découvrir la revue

Citer ce document

Adams, H., Behler, E., Birus, H., Derrida, J., Iser, W., Krieger, M., Miller, H., Pfeiffer, L., Readings, B., Wang, C.-h. \& Yu, P. (1996). Ludwig Pfeiffer's "Culture and the Humanities: Symptomatologies, Mostly Historical, Mainly German": Roundtable Discussion. Surfaces, 6. https://doi.org/10.7202/1064842ar

\section{Résumé de l'article}

Ces discussions autour du texte de Ludwig Pfeiffer, « Culture and the Humanities: Symptomatologies, Mostly Historical, Mainly German ", ont eu lieu en avril 1994, dans le cadre du premier Congrès sur le Discours Humaniste. Les communications de cette première réunion du Congrès ont été publiées dans le volume 4 de Surfaces (1994).
Copyright (c) Hazard Adams, Ernst Behler, Hendrik Birus, Jacques Derrida, Wolfgang Iser, Murray Krieger, Hillis Miller, Ludwig Pfeiffer, Bill Readings, Ching-hsien Wang et Pauline Yu, 1996
Ce document est protégé par la loi sur le droit d'auteur. L’utilisation des services d'Érudit (y compris la reproduction) est assujettie à sa politique d'utilisation que vous pouvez consulter en ligne.

https://apropos.erudit.org/fr/usagers/politique-dutilisation/ 


\title{
Ludwig Pfeiffer's "Culture and the Humanities: Symptomatologies, Mostly Historical, Mainly German" \\ Roundtable Discussion
}

\author{
Hazard Adams \\ Ernst Behler \\ Hendrick Birus \\ Jacques Derrida \\ Wolfgang Iser \\ Murray Krieger \\ Hillis Miller \\ Ludwig Pfeiffer \\ Bill Readings \\ Ching-hsien Wang \\ Pauline $\mathrm{Yu}$
}

Surfaces Vol. VI.105 (v.1.0A - 13/08/1996) - ISSN:

1188-2492

Copyright for texts published in Surfaces remains the property of authors. However, any further publication should be accompanied by an acknowledgement of Surfaces as the place of initial publication.

\begin{abstract}
This roundtable discussion of "Culture and the Humanities: Symptomatologies, Mostly Historical, Mainly German", Ludwig Pfeiffer's contribution to the first International Conference for Humanistic Discourses, was held in April, 1994. The papers of this first meeting of the ICHD have been published in volume 4 of Surfaces (1994).
\end{abstract}




\section{RÉSUMÉ}

Ces discussions autour du texte de Ludwig Pfeiffer, "Culture and the Humanities: Symptomatologies, Mostly Historical, Mainly German", ont eu lieu en avril 1994, dans le cadre du premier Congrès sur le Discours Humaniste. Les communications de cette première réunion du Congrès ont été publiées dans le volume 4 de Surfaces (1994).

Pfeiffer : I've written a paper of a type which we have rightly come to despise thoroughly, namely explanatory narratives. And to make matters worse, there are stories in my paper, I think, in which theoretical, conceptual, and institutional aspects interpenetrate all the time, and sometimes, I think, in very blurring ways.

Interpenetrations which do not live up either to the standards of Begriffsgeschichte (yesterday), nor to, let's say, the expertise Ernst displayed in talking about the Romantics. So I'm mentioning Romantic hermeneutics in a way which might seem contradictory, or at least out of joint with respect to Ernst, but I personally don't think it's the case. Anyway, nor do these remarks pose as theory on the one, or as essays in the sociology of knowledge on the other hand. Yet I have remained, since my Constance days, in effect I have remained in love with the notion of a neglected German philosopher, Wilhelm Schapp, and the idea of being all the time enmeshed or involved in histories... well, stories... stories neither completely singular, nor sufficiently symptomatic or paradigmatic, but perhaps capable of producing some repercussions in other contexts. Thus I would like to look upon them borrowing the title of a collection of stories by Harold Brodkey, I would look upon this thing as stories in an almost (emphasizing the "almost") classical mode. First point. Perhaps one might ask in a kind of systems theoretical premise or orientation, namely, what happens cognitively once institutionalization takes place in a massive way, that is to say, in a really significant and massive way? My guess would be that the activities which the humanities perform can bear only a limited amount of institutionalized realities. And here I would join Ernst's paper and the idea that the real humanists were not normally in the humanistic disciplines or in the humanities departments. And I have taken up that topic with a complaint about the (in German) "Geistlosigkeit," 
the lack of spirit, or the lack of... whatever one may see in that - maybe the lack of fascination, in humanities departments. Institutionalization, looking at it historically, seems to eat up the relevance which called institutionalization into being. That is an almost paradoxical effect that once you institutionalize something, it seems to eat up the relevance, and not to promote it. What called the institutionalization into being (in one phrase which I steal from Luhmann) one could say truth and relevance, automatically become scarce resources once institutionalization takes place. Now for Germany, I take Dilthey to represent ... and of course that's just one choice, but I take Dilthey to represent the crucial effort to weld together, to weld together, or to yoke together, life already seen as social differentiation by Dilthey on the one hand, theory on the other, and institutionalization on the third hand. The unity of the world is no longer to be confused with feelings of life, feeling of a totality of life, as manifested, for instance, according to Dilthey, in Shakespeare, Raphael, Luther, Beethoven, and maybe Goethe. But that unity of the world has to be fabricated conceptually and institutionally. I might mention that, for England and the US, the same problem has been linked to the breakdown of a socio-culturally representative liberalism, of the type, let's say, represented even by John Stuart Mill, and other variants, and the reaction of people in the States like Babbitt against that breakdown, by mobilizing literature as the humanizing force. So that would be the first point.

Second point. The cultural, perhaps partly cognitive import of institutionalization - and here I'm not sure what the English idiom is anymore, here I probably put my foot both down and in it - may have come to the forefront with a certain cultural generalization, by turning, you might say, into a cultural paradigm of the interrelation, not to say the interpenetration, of literature, or what we have come to call literature, and the various modes of its interpretations since the nineteenth century. I'm laboring under the impression or delusion that ideological urges of whichever kind have been more easily expended on literature in literary interpretation, in the past at any rate, and now in the present maybe again, than on the other so-called arts, that we have immeasurably more chairs (and I'm asking, really, myself why we do have that) we have immeasurably more chairs for national literatures, also even for comparative literature, than for instance for other arts, like music and so forth. Nobody would think apparently of establishing a chair for German music or Italian music. And I guess that that means something, 
whatever it means, but I think it is at least symptomatic. That therefore also the urge to get rid of that - for instance, in theories of aesthetic effect in deconstruction, or also in the cruder forms of political correctness, as well as in the more sophisticated forms of inter-cultural theories - that this contemporary urge to get rid of these ideological burdens has therefore, in literature also, been stronger. Put as a primitive question to American and Asian colleagues, what is the status of dead white men who were composers and not literary people, or painters? And here I think I would like to tie up with what Hillis put forward - I'm not sure whether it was a concern or an anxiety about literature being pushed aside by different orientations or whether it is seen as a kind of... well, expectable development. In the present, I would say that one has to push this back also into the past and see that maybe before the nineteenth century, the situation may have been similar to what's coming now. I mean, different of course, but the structures of, let me call it media orientation, may have been different from what our emphasis on literary history has made them out to be. One could see some contemporary literary theory as an internal effort (that is to say, within literature and literary studies), as an internal effort to break up, or at least continuously undermine the cultural mésalliance of literature and interpretation, while at the same time reasserting the importance of literature. I think there are interesting remarks to that effect in Wolfgang's initial pages in The Fictive and the Imaginary, where he talks about literature being pushed back as a paradigm of culture, but at the same time then goes on to reassert its, let's say, now anthropological status. That would be the second point, which I think we have touched already upon.

Third point. While I may be entirely wrong on this second point, I am fairly uncertain of a third one, which refers to the end of the paper. Literature in the shapes we are normally dealing with marks both progressive increases in cultural complexity and a retreat. In spite of what we have been saying, to some extent, about what literature does, I think it marks also a retreat from, let's say, the performative dimensions of culture. I'm not saying that there is a contradiction between complexity and performance, but I do think that there is a tendency towards a retreat from cultural performance. LeroiGourhan, in his Le Geste et la parole, has, for instance, a very strong thesis (which is not in the center of his argument, but still it's a strong thesis) talking about a misleading overemphasis on the symbolic, and that in this case means the discursive, the literary, or 
theoretical interpretation and treating of culture. Let me, for brevity's sake, quote an American colleague to that effect, whom I am not so much in the habit of quoting. And in this context especially, I don't quite know what sensibilities I may touch by quoting him, but still I do it. He has been mentioned before here. His name is Stanley Fish. That's from that book of his, Doing What Naturally Comes. And although I don't quite know what he's driving at, I would know what I would be driving at if that statement were referring, let's say, to Germany. So I don't know what he's driving at with respect to the American scene, but yet I'd like to quote him: "If there is anything like a crisis in English studies, it is a crisis in confidence, and it is one that we have in part created by taking ourselves too seriously as a priesthood of a culture already made, and not seriously enough as professionals whose business is to make and remake that culture." I think this would be my last remark. I don't know what he's driving at, but I see some relevance with what I'm talking about with respect to Germany. Thanks.

Krieger : I'm going to refer more to your paper than to your remarks today. And as a matter of fact, I see a certain discontinuity between them. If I'd heard your remarks, I wouldn't have identified you as the author of the paper, but that may indicate your own development since you've written it. The paper does, in many ways, repeat from another perspective and with much less emphasis on the Begriffsgeschichte, the territory we thought we covered with Hendrik yesterday. The sequence from Geisteswissenschaft to Kulturwissenschaften runs from Kant to Dilthey to the present moment. The paper is a narrative. I think it's more of a narrative than you perhaps suggested. You say it is a number of small stories, but I think your small stories have a master narrative, and I think there is a perspectival point toward which it moves, even though it is a point of dispersion. And in this narrative, it's, as I said, all of the Geist moving to the Kultur, and then to the dispersal. And it is a story of the failure of unity, the failure to achieve the merging together of the discourses into the humanities. As I said, we're still with the Begriff because the question of Geisteswissenschaften is at the center of why the Geist didn't work; then we come to the Kultur and why the Kultur apparently isn't working, because the culture involved is a culture of dispersion, increasingly dispersed. We talked so much about technology, and so on, yesterday with Jacques, and I think that issue is implied, of course, in the later stages of this paper. You have a story early on of the two ways of dealing with literature, the exegetical way and the hermeneutic way, and you have a certain opposition, 
though I think these are not your best words for this. But in a sense the exegetical is the tradition from the Poetics and Rhetoric of Aristotle onward, in which you're looking at in an a-historical, essentially non-contextual way; that is, even if it talks about history and uses literature as examples of history, it is not really historicizing the literary text within the context of its cultural Geist. And on the other hand there is the hermeneutic tradition, which is contextualized at every moment. You're dealing with this opposition again and again and insist that the difficulty with the opposition is that unfortunately the opposition is too strong. The one side, the separatist view of the literary or of the aesthetic, has all the failings that accompany the loss of the Geist, the cultural. In the contextualized one there is no unity of context, and again and again the Geist fails, and for that reason the attempt to contextualize is incomplete because there is no context, no unity of context, no merging of contexts, for all the noble efforts of the German scholars who would try to create one. So there are these little stories built in which repeat at different stages the impossibility of merging that which is dispersing. On the other hand, there is the difficulty of somehow unsatisfactorily dealing in too much isolation, too non-contextualized or nonhistoricized isolation, with the aesthetic. Until we come to the final calculated dispersion of the contemporary mode, in which Ludwig suggests we should lose the habit of isolating the literary, should substitute the notion of media, and get involved in some apologies for the media as we have them in contemporary culture. He suggests that we replace the literary with the notion of the media and try somehow to make these into cultural elements, even as we recognize that they are totally elements of dispersion. A number of problems obviously arise, and all of them have to do with the narrative structure of the history. I wanted to raise as a general question, really beyond the paper but one which it seems to me has been on the edges of our discussion, the problem of the relation of history to the idea of progress. To what extent has the myth of progress been implicitly involved in some of our constructions of historical narratives? I remember at one point when Hillis said to me yesterday with some force, when I complained about the fact that we could never say Moby Dick is better than Uncle Tom's Cabin or something: "That way of thinking, you might as well face it, it's gone." And maybe it is, but it seems to me we have the problem, whenever we say that we never can think that way again, pointing to some point in the past in which we thought a certain way, that the myth of progress is at work. In my own paper, I spoke of oscillations. I don't suggest for a moment that we ever go back and forth and that the same thing ever 
does get repeated. There is no repetition in any simple sense. I think I would argue about repetition as Paul de Man does in dealing with it in the Kierkegaardian sense. We never repeat. But neither do we ever repeat ourselves in the future. And the privileging of our moment with respect to other moments in the past, and the assumption that because ours is later it is always better, these are things we do have to worry about. History does tend to feel teleological every time we recite it. And I'm wondering, because of the historical character of your own presentation, how does this square with what we were saying yesterday a number of times, Hillis as well as the others (Hillis said it first yesterday): the fact that we're also making new starts and that we are both in and out of history? To what extent are we destined to be trapped, let's say, by the media as a replacement for the literary because the media are there?

Pfeiffer : Including the literary. It's not a replacement, that. It's just an internal shifting.

Krieger : We'll place it in our own way of thinking; that is, using the literary as you do through here as essentially a term for a separatist literary aesthetic.

Pfeiffer : Since the nineteenth century.

Krieger : Anyway, these are some of the questions I have I wanted to recapitulate your paper somewhat because it seemed to me that some of the problems it presents are different from the problems that you raised this morning.

Pfeiffer : Oh. Well, it's important for me, that. I mean, I would first like to subscribe to Hillis saying that you cannot really decide anymore between Moby Dick and Uncle Tom's Cabin. I think that's really hard. You will have to find certain reasoning or have to specify why you deal with Moby Dick as an exemplification of a special, let's say, special importance of a complex text in a given situation.

Krieger : I wasn't suggesting "better" in any Platonic sense.

Pfeiffer : No, no, no.

Krieger : I mean, obviously under certain conditions. 
Pfeiffer : But it's important to me that this, what you call the, let's say, the separation of literature, is not really separation at all.

Krieger : It seems to me that you have a separatist notion too. You narrate a conflict between the exegetical, which in some sense is history-free, or insufficiently historically involved, and the hermeneutical, which is an attempt at a much more complete Geisteswissenschaften way.

Pfeiffer : No, I don't think I would say that. I think the Poetics and Rhetoric, of course, are socially much better grounded than hermeneutics afterwards. Hermeneutics, I think, has the problems, or some of the problems it has, because it is unsure how to go about its social/historical grounding.

Krieger : You do say that too. That's the failure on the other side.

Pfeiffer : Yes, yes. That would be for me the important point. And with respect to literature, I think what hermeneutics signals or is symptomatic of, is the generalization of literature at a time in which it was really becoming a specialized affair. And I think we, in our institutionalized areas, are still a kind of reflection of this problematic generalization of what in fact has become a more specialized affair. And in fact, I think, always was a more specialized affair than our, let's say, histories of literature or poetics had made it out to be. In that sense, of course, our situation is different from the situation, let's say, in the past, before the nineteenth century. But I do see more analogies to the situations before this generalization of a specialization in the nineteenth century than differences, because I think that the position of literature within cultures before the nineteenth century may have been in fact more similar to our situation than we normally think. In that sense, there is a historical development. And we are not repeating the same situation, but still I do see some analogies.

Krieger : By the way, it is interesting that it was Jacques Derrida who, sometimes surprisingly, has leapt in and said, let's not forget the special exemplary character of the literary.

Pfeiffer : Yes. And I would agree to that, that the question is whether it does that all the time, and in which way it does it at given historical moments? And there I think we have generalized too much, or we may generalize too much. 
Behler : I appreciated many parts of your paper in which you talk about the impact of institutionalization and its stifling effect upon humanistic discourse. I won't go into that because we seem to agree on these aspects to a great deal. I want to take up your challenge concerning Romantic hermeneutics, and want to approach one section of your paper from that point of view, namely, the analysis of the failure of unity, or the failure of Geist, spirit, as a foundation of the humanities during the course of the nineteenth century. I was surprised that you did not devote much time and reflection to the rise of the historical consciousness, which is of course a major factor, for this breakdown of the Hegelian system and the Hegelian notion of Geist. Romanticism contributed a great deal to the flourishing of the historical sciences during the nineteenth century, to the rise of a history of religion, history of law, history of art, and history of literature. These are all impacts of Romanticism and the historical consciousness created by Romanticism. In this rise of the historical consciousness, I see an implied critique of the solid foundation of the Geisteswissenschaften on the basis of Geist, because now Geist becomes historicized, undermined, deconstructed through the historical consciousness. This process of losing and reappropriation that you, at the end, seem to propose as a solution to the crisis of humanistic discourse, seems to me anticipated by the historical consciousness, especially in the radicalized form of historicism, and even more radicalized in the form of facticity and historicism pronounced by Heidegger and taken up by Gadamer. I'm asking you whether this could not be seen, because of Gadamer, in relation to Romantic hermeneutics, and whether his dialogical model of interpretation is not corresponding to what you said toward the end of your introduction this morning about the making, the loss, and the remaking of culture. This is just one question I have here.

Pfeiffer : I would not quite know to what extent I would take the development of historical consciousness out of the Geisteswissenschaften as a development of the nineteenth century. In that development, one certainly had approaches taking, let's say (difficult to find a term which is not misleading), the more material aspects of cultures into account. If you refer in particular to a development from Romantic hermeneutics via historical consciousness down to Gadamer, then I think with Gadamer you clearly see the ongoing anchoring of the Geisteswissenschaften in Geist. The dialogue with the past is, well, is a kind of dialogue between, should I say spirits or ghosts? It's clearly cultural heros talking to 
each other as representatives of Geist, There is no deviance from this, in that respect in Gadamer. The deviance is rather in methodological terms, how you go about producing this dialogue with the Geist of the past. But not in the levels to which this dialogue refers, I think. Within the historical consciousness, I think there are indeed approaches towards what, in another context one could call material culture, although that's misleading now because the term "material" came up in Hillis's paper with respect to Paul de Man.

Iser : There is also a tradition that runs counter to what you have outlined; I refer to what Ernst has pointed out. If you think of Droysen who had been largely forgotten throughout the nineteenth century as he didn't fit into the overriding picture by not having a unifying principle of sorts. The moment foundational principles came under attack, Droysen emerged as a major figure and his work became paradigmatic for a hermeneutical approach to history. Foundational discourses lay claim to an overall explanation, whereas hermeneutical principles are set to explore what seems to be hidden. Tradition is marked by such a countervailing tendency.

But that's not actually what I wanted to say. First, perhaps, one remark about ideology, because I'm a little bit nervous about this term as it floats around in our discussion. Ideology entails a reification of a presupposition. This may be one of the reasons why ideology critique is now on the wane. A mutual criticizing of one's presuppositions has become tedious. Reifications of concepts parade in the trappings of reality, and are meant to be taken for reality. If we look at the changing sequence of reifications, we get a kind of negative history of foundational discourses. The principle underlying the previous discourse became the target of criticism for the following one, which is structurally exactly similar to the one denounced. What changes is only the content of the reified explanatory principle. As the foundational principle cannot logically be the ground out of which everything arises, because the ground as an assumed reality cannot produce another reality, this deficiency gives rise to the power play of ideologies.

The other question I should like to comment on concerns the idea entertained by semioticians regarding literature as being a privileged type of text. If there is a text, let's say, like Moby Dick, which allows for accommodating more interpretive systems (in the semiotic sense of the term), then Uncle Tom's Cabin appears to be an inferior one. I should not call such a qualification ideological. A 
multiplicity of interpretive systems does highlight the multifariousness of viewing, approaching, and even conceptualizing what is to be grasped. And such a multifacetness is almost the exact contrary to the onedimensional frame that determines ideology.

Miller : I was worried quite a bit by what Jacques said yesterday about complexity, because I'm tempted by that myself, to say, after all, Moby Dick is much more complicated, therefore more interesting, therefore more worthy of our attention than Uncle Tom's Cabin. That's to appeal to a criterion which is itself ideological. There's no intrinsic virtue in complexity that I can see. And as far as measuring...

Iser : I didn't say that.

Miller : No, well, Jacques seemed to be saying it.

Iser : Yes.

Miller : But I'm getting back around to what you did say. Also, I'm not so sure that Uncle Tom's Cabin is not open to just as many interpretations... as a little poem by Wordsworth, "Like a Slumber Did My Spirit Seal," which is just a few little words down there on paper, is open to at least as many interpretive systems as Moby Dick...

Krieger : But that's poetry. And therefore privileged.

Miller : Well, I don't know about that. It's not quite clear why it's poetry, because it's open to many interpretations. It's certainly not poetry because it's complex in the way it sounded like Jacques meant it. In other words, I've the feeling that these are attempts at recuperation that might not in the end be really any different from my saying, Moby Dick is a great work by a central figure in our tradition. I know what that tradition is. These are the canonical works.

Iser : Accommodating many different interpretive systems is not meant to qualify the text concerned in terms of complexity. Instead, each interpretive system turns into a sign for establishing relations with other interpretive systems. It's not that different persons apply different systems to the text for its interpretation, in order to bring out its complexity; instead, each system turns into a sign for another object and for another interpretant in semiotic terms. Therefore it is not a question of complexity so much as one in which the very many systems establish relationships as Peirce has maintained. The more we think in terms of relationships, the easier it would be to expose foundational principles 
for what they are. We may not be able to dispense with them, but they are not the be-all and end-all, and whenever we institutionalize them, we get in trouble.

Miller : If you were to institutionalize that Peircean paradigm, then my question would be, what good would it be - social good, human good, Geist good - - to do that? Why would one want to do that, or to teach one's students to do it? What good is it? It's obviously intellectually very attractive, and you might have given an answer by saying just that.

Iser : First of all it is the very multifariousness of grasping things to which we become alerted thereby. As far as cultural studies is concerned, we might be better off by realizing and observing such a multifariousness of relationships that will prevent us from foreshortening our assessment by jumping to ideology-inspired conclusions. I would still maintain relationship versus subsumption is an important alternative in view of the current cultural code.

Readings : Before I say what I have to say to Ludwig, I'd like to say, the danger is with the constant temptation to confuse history and prescription, that is to say, to want to deduce a law from history. And that becomes to me very conservative and very dangerous. That is to say, one always risks confusing "The Bible has accommodated a wide range of interpretation, therefore can accommodate a wide range of interpretation." There seems to me to be absolutely no logical argument, no logical link between the two statements. That is, there is nothing in the Bible (I mean, and that would seem to me to be the example of Wordsworth) that says, it is in the nature of this text. When the semioticians refine that and say each interpretation becomes an interpretamen, and so on and so on, then what they're doing is, I think, acknowledging that question, but still trying to slip in some kind of a deduction of historical necessity, which is then inherently ideological, because you end up saying, because these interpretations have been produced, therefore we shall continue to work on them, we shall focus on them or privilege them.

Iser : No not necessarily, because all of them are historically conditioned (and what is not historically conditioned or at least pretends not to be so is ideological).

Readings : Absolutely. 
Iser : Just to come back to the Bible for a moment. For the Church fathers it had four senses, i.e. it accommodated already four interpretive systems. Obviously, many more were added in the course of history, which should not be dismissed.

Readings : Well, I want to talk to Ludwig, so I will quickly move on. I just think there's no prescriptive ground to be drawn there. But what I want to say to Ludwig has to do with what I understand to be the problem of what it means to institute, with the institutionalization of culture in the modern university. I agree with your impulse to systems theory. However, I think there is more discontinuity to the question of what gets institutionalized and to what we might call the idea of the university than you perhaps admit. I think Schiller is more important here in the way in which the notion of aesthetic education thematizes for the first time the replacement of Church by university, and opens up the post-Kantian space. Kant wants to make reason the idea of the university, and Schiller wants to make something which I would translate into English as "culture" into the idea of the university, in its double articulation. That seems to me to be the crucial shift, because it involves precisely the notion of history. That is to say that the question of historical reworking, the lost immediacy of life, is there in Schiller. The Greeks had an immediacy. We have lost it in the fragmentation and specialization of our disciplinary life. We can reconstitute that unity conceptually - at which point, the emergence of literature (and here I can't speak with great detail of Germany). What interests me is the question of why literature replaces philosophy, through the course of the nineteenth century, as the center of the university, that is to say, the idea of the university, whereas it is very clear for Humboldt that he's going name philosophy as the discipline. (And that gives him a false continuity with Kant, because it seems to me that what Humboldt means by "philosophy" has nothing to do with what Kant means.) I think that the subject that you raise, the question of the subject, the metonymic subject who will stand for the whole university in Fichte, is much more of a reality in the eighteenth and nineteenth century than you give it. I think people do believe that Jordan, the man who founded Stanford and went to Indiana and started English, or - I'm blocking on the man from Harvard, the lectures that T. S. Eliot, that people give...

Yu : Charles Eliot Norton? 
Readings : Thank you. Charles Eliot Norton. That kind of person really does stand for, is the subject of an intellectual life, at that point, right? When literature emerges in Britain, at least, it is crucially because of the relationship between the Church and the state is different. And I think there's a very important issue. That is to say, whereas for the Germans it's very very important for there to be a modern nation-state that is distinct from the Church, thus anti-ecclesiastical, in a country like Britain, where there is no separation of Church and state, where until 1874, the Anglican Church controls the institution of the university, then literature is going to emerge in a way philosophy isn't. And I think that the influence of Britain is very important on the development of the notion of literature. All of that to say that I think that your impulse is dead right, but that I think the reason for the symptom is complex. What is national literature a symptom of? I would say, national literature is, very simply, a symptom of the nation-state as the site at which capitalism reproduces itself, rather than the other way round. And that's the great mistake (I'm not accusing you of making it) that we tend to make. We tend to think that, you know, literature precedes the nation-state, rather than the other way round.

Pfeiffer : Well, that was my thesis.

Readings : Yes. At which point, what I would argue is not that where we go now is expanding the notion of literature across media. If you recognize the essential link between the emergence of national literature and the nation-state, the historical function of comparative literature as a kind of 2001 fantasy, either you have the Goethean model of world literature, or you have the notion that somehow what we need is a U.N. literature that will solve our problems. I think we have to recognize that the contemporary (and I speak too fast, crystal ball gazing) the contemporary disappearance of the nationstate, that is to say, the decentralization of the nationstate, means that precisely the model of national literature is not a model that we should be thinking of expanding or spreading across the humanities. I think it's actually a more fundamental work that's required of us, which is to rethink the humanities outside the notion of the reproduction of the subject of the nation-state, that is to say, in its most fundamental sense, the humanities outside the notion of culture at all. I would say that culture in its modern sense is the reproduction of subjects. It's that dual Wissenschaften/Bildung. You find the knowledge of the nation-state's identity, and then you inclulcate it at the same time. In the Fichtean 
analogy, you have that wonderful remark about them being clothed in uniforms. In fact, Fichte says, "Education is the mutual unveiling of students and professors to each other, " which presumes that they are ripping off these uniforms to... He produces that metaphor in relation to the question of what happens in the classroom, and he says, "The moment of gaining of consciousness opens onto an eternity." That temporality, that double temporality of the instant and the eternal in culture seems to me to be so fundamentally axiomatically pinned on the nation-state that we're in a very tricky position now.

Pfeiffer : First, Wolfgang, one remark about Droysen. I mean, I know nothing about him, but it struck me when I read about that. He doesn't have these foundational principles, that's correct?

Iser : Correct.

Pfeiffer : I would still have considered him to be typical for my type of argument, since instead of foundational principles, he suddenly seizes certain myths with which to supplant the missing basis normally provided by the foundational principles. For instance, in historical interpretation, the myth that the Hohenzollern are the legitimate successors of the medieval Hohenstaufen.

Iser : There are myths both for ends and beginnings.

Pfeiffer : Yes, yes, alright. But still these figures of thought come up. I mean, I don't know enough about that. I wouldn't assert that. The question of the privileged text: I don't see it as an ideological term. There I wouldn't go as far as Hillis. But even if you formulate the problem in terms of relationships and privileged texts, you need orientations or reasons or motivations in order to treat it. I mean, even if you look at relationships, they have to be phrased in some kind of... well, interest (I'm not really clinging to the Habermasian term, but) in which you see them. And that, I think, is the meaning of what somebody (somewhat cynically, I think) called "attractive" disguises of productive postulates. I mean, you need something which is problematic, but which still provides sufficient ground for dealing with these things.

Iser : The disclosure of what one intends to do would be an answer to that.

Pfeiffer : Well, but that is...

Iser : I'm not defending semiotics. 
Pfeiffer : This is why I'm always a little bit uneasy with terms like monitoring or watching, because they do not give us any hint from which perspective you are monitoring.

Iser : It implies that you have continually to shift your perspectives of comprehending and grasping, in order to avoid the pitfalls by commiting yourself to definitive stances or positions.

Pfeiffer : But of course the direction in which these perspectives may be shifting is left to...

Iser : It is the unpredictable other.

Pfeiffer : To Bill. I'm not clear about Schiller. Although he introduces that notion of culture, he seems to be going from a culture of play, or of grace towards a culture of dignity, and that seems to me, at least, to be an altogether different affair, maybe not so different then, after all, from Kant. I wasn't quite clear into which direction your argument about England, and literature occupying, let's say, the space between the Church and the state was going. I see it as an analogous argument, or an analogous situation to the German situation. I mean, literature takes on very clearly in Matthew Arnold a very central cultural function.

Readings : Yes, but what I'm saying is the direction Matthew Arnold takes in "The Function of Criticism at the Present Time." One of the great confusions of all undergraduates is that you give them "The Function of Criticism at the Present Time," and they don't understand, they can't understand what Matthew Arnold means by criticism, because he's taking something which he understands to be philosophy on some level, and philology, and inserting it in England into what I will call literary criticism. To be imperialist, now, I will say, when we talk about national literature departments, Matthew Arnold performs (for me anyway) a very crucial shift in switching philosophy and philology towards something that is recognizably contemporary literary studies. That's a shift that takes place around him, and it takes place because of this peculiar institutional configuration of Church and state. And that's why Leavis will emerge and make the most insane claims for the relationship of modern poetry and literary criticism and their capacity to save a small proportion of the world and thereby make the world, you know, a livable place once again. I don't know enough about Germany. It seems to me to be a more strongly literary thing than what Dilthey and the 
hermeneutic movement is doing, in its appeal to the metaphor of reading or translation.

Pfeiffer : Yes, although I think there is a tendency in Dilthey to privilege literature in that kind of unifying function. I think so anyway...

Behler : Not on religious grounds. It's on grounds of pseudo or semi-religion, like Hegel's Geist, which is not the British model, not at all.

Pfeiffer : Well, life takes shape first and foremost in literature. I mean, literature for him is a shape which is both concrete and intelligible at the same time, not in the Platonic sense.

Adams : As this conversation went on, I imagined myself coming in off the street and suddenly hearing it, and as a matter of fact, that's what I have done. I haven't been around for the earlier discussions, but one of the things that strikes me these days is (I think Murray agrees) that arguments very frequently reduce themselves to discourse about the evil of foundationalism, and everyone attempting to avoid being tagged with that word as long as is humanly possible. This strikes me as a sure way to boredom, and it appears to me that we don't get very far when we get to that argument. By the same token, I think, the argument having to do with complexity that Wolfgang and Hillis were having ends up in about the same place. That is, we finally come to the point where we don't want to argue that any longer. We become bored with it, so that we fall back upon statements made by previous people about it, such as Blake's statement that "There's a great gulf between simplicity and insipidity." And the notion that some kind of distinction can be made, somehow or other, between his poems and the poems that he parodies by Anna Barbauld. I don't know where one goes from that, but in fact it seems to me that we haven't gotten very much farther than the argument that we soon lose interest in Barbauld, whereas we seem somehow not to lose interest in Blake's poems. Why? When we try to explain in any way why that occurs to us, we end up making some kind of ideological statement. I think there's no doubt about that. So that it seems to me that the kind of judgment that we're making there has to be tacit, and once it ceases to be tacit, it becomes ideological. That's just some general remarks.

Krieger : Is that to suggest that there's an ideology behind the tacit judgment? 
Adams : Probably, once the tacit judgment is actually articulated, then I think it can't help but be ideologically framed.

Miller : Everybody's talking as though that would be a terrible thing. If it's inevitable I think we need...

Yu : Just recognize it.

Miller : Why should we want it to be otherwise?

Adams : It's obvious that one could counter by saying, well, there are ways in which Anna Barbauld's poems are very very interesting, and that's certainly true. They're also very very boring from another point of view.

Now, my second point has to do with the idea of a university. The idea of the university is not literarily grounded in this country. It never has been, I think. And it's certainly not philosophically grounded, never has been. It's grounded on practical science, set up and supported with huge amounts of money from the federal government under the guise of national defense. But two things have happened. One, of course, is that those people who were being supported in that way were not particularly interested in national defense. And secondly, whatever the original impulse was, it has now mindlessly gone astray. But for us to sit around and talk about the idea of the university as somehow, at least in this country, centered on what we do is just plain madness, of a sort that F. R. Leavis would at least have recognized.

The third point has to do with institutionalization. There are different kinds of institutionalization. I get a little nervous when I start to hear that term used in a general and pervasive kind of way, because I can think of numerous kinds of institutions that are quite different and form themselves quite differently. One of the things that I've noticed in the papers and in the conversations is that one kind of institutionalization is no longer ever mentioned, but used to be fairly important, and that was the institution of writing itself, that is, the institution of what we now call creative writers. One of the interesting things, I think, about recent literary theory in general is how separated it has become from the direct interests of the people who produce the literature that's being discussed. Now that strikes me as a very interesting matter. It has to do with questions of patronage, the history of questions of patronage, the attitudes of writers, the institutionalization of literary criticism, the role that the writer sees himself or herself performing in 
the culture, which is almost always, in our time, antithetical, I think. Those kinds of questions seem to me to get lost somehow, both as historical questions and as theoretical ones. Let me give you just an example of what I mean. In my anthologies, Critical Theory Since Plato and Critical Theory Since 1965, I do not believe that there is a what we now call an imaginative writer represented since the time of the new critics, and those people, like Ransom and Blackmur, were critics, and writers, sometimes failed writers. Then you look before that date, and you find almost no one who was a literary scholar in the sense in which we think of the term. What you find is either philosophers writing about aesthetics, or some specific kind of problem which we see is relevant to it, or writers themselves defending what they do and making it possible for us to think about the implications of those things. That's all drastically changed, and it seems to me a very important change, and it has to do with the institutionalization, I think, of literary study in a certain kind of way in our culture (and I'm talking about American culture here), which has led, for example, to the shifting and establishment of a new form of patronage, which is fundamentally the university. Even for writers who do not identify themselves with the university, they remain very frequently funded by them in one way or another. And it just strikes me that it would be important to look at that phenomenon a little more closely, and see indeed whether the writer's perspective has not been somehow shoved under the carpet. We are talking now about a humanistic discourse that isn't literary at all.

Krieger : Hazard, about what you said about recent theorists: in them you don't see any references to the people about whom they're presemably writing, but I don't think most literary theorists of the past couple of decades would for a moment suggest literature, or the writings of the creative writers, were their subject.

Adams : Well, I was saying two things: saying that, and secondly that there simply are no creative writers I know of who get into anthologies...

Readings : Blanchot? Blanchot? Kristeva? Cixous?

Adams : What's that?

Readings : Blanchot would seem to me to be a countercase.

Adams : Oh, well, now, there are a few, but I'm thinking of American culture. 
Krieger : We have a creative writer in our midst. Do you want to speak at this point, or do you join the list?

Wang : No, I will just follow.

Krieger : You want to join the list.

Adams : I think that both of these things are significant facts, and they tend to have the result of creating some kind of alienation of literary scholarship from itself or from its own subject matter.

Krieger : Of course, Bill Readings might say that (forgive me putting words in your mouth) that this would be one example of the way in which humanistic discourses are escaping their national cultures and are being internationalized in the international movement in theoretical discourse that has no relationship to the individual national literatures.

Adams : Possibly.

Birus : I would like to make some reflections on the first part of your paper, and especially the inscription "The Humanities and/as Hermeneutics," the concept of hermeneutics. You deal with hermeneutics irrespective of this final stage of hermeneutics in the sixties and seventies in Germany, as Gadamer, Habermas and others dealt with 'Universal hermeneutics'. And I would like to make some historical remarks that could make this "and/ as" more fluid, and at the same time more precise, I think. You begin then the second paragraph with: "Traditionally, that is since the Middle Ages down to the 18th century, hermeneutics," and so on. And I would say there is a danger to over-emphasize the role of hermeneutics in that period, up until Schleiermacher, it was only an 'auxiliary discipline.' Yes, like the word "humanist," it had such a touch of classroom atmosphere. Schleiermacher wanted to be dispensed to teach it, because it was only a tutorial thing, let's say, for undergraduates in theology, in law school, in philology, but it was in no way a prestigious part of the humanities. And then, with respect to Schleiermacher, you speak about "the privilege of literature and hermeneutics." But Schleiermacher's hermeneutics was written "with respect to the New Testament."

Pfeiffer : Of course.

Birus : And in the hermeneutical reflections of Schleiermacher as well of his former pupil Boeckh, there is nearly no dealing with literary texts. The other thing is 
a reduction of hermeneutics as opposed to what could be called 'structuralism.' Hermeneutics in Schleiermacher had a double - if not a triple - orientation. The one branch was what he called grammatical interpretation, that deals with texts only with respect to the language and to the linguistic conventions at that time the text was written. So, there is absolutely no cultural contextualizing, and such things. It is like 'new criticism,' taking a text as a piece of highly organized language. The other branch has the very misleading name "psychological" interpretation. Before, Schleiermacher used the name "historical interpretation," but there he was fearful of misunderstandings. And that indeed means: forget language and that it is written; look for the context in the life of the author; was the text planned as a main work, or was it only a draft sketch? and so on. Look in the life of the group he lives in, the generation, the nation, and so on. The first branch deals with a text in a semiological way, the other in a cultural, anthropological way. Karlheinz Stierle's book titled Text als Handlung (Text as Action) is a quite good slogan for this second aspect of hermeneutics, the text as a pragmatical event. And then the third aspect, not really systematically well managed by Schleiermacher, the socalled "technical interpretation." It means the organization of this work with respect to genre and other conventions.

Iser : But this applies equally to psychology which he made into a frame of reference.

Birus : Yes, yes. And then you can see again in the classroom atmosphere of Boeckh, there enters the question of different ways of interpretation, and so on. But I think to put these questions about the role of "the humanities and/as hermeneutics," it's necessary to deal with Begriffs geschichte of hermeneutics and of humanities. And my last remark with respect to page two: it's not accurate to say that Boeckh identified classical philology, exegesis, and hermeneutics.

Krieger : Of course, Hendrik, it's not the first time in history that the person who uses a term for the first time doesn't own the term and cannot control its future transformations, reductions, or anything else. We can begin with Aristotle's term "rhetoric," of course, and we see all the radical changes it has undergone. We can't say each time, oh my God, that's wrong because we go back to Aristotle, and he owns it, and limits the possible meanings we give it. 
Birus : No. I completely agree, but the shoulders on what we stand have to be shoulders of giants. And I think the shoulders of Gadamer and others are very weak shoulders to ask for foundations of humanities.

Krieger : Hendrik, my only point here is that you can argue that about Gadamer, and argue it theoretically, strongly, and persuasively perhaps, but the justification of your argument cannot rest on the fact he's not adhering to all that Schleiermacher made available. If what Schleiermacher made available is better on theoretical grounds, then by all means, let's go back.

Pfeiffer : Yes, yes, okay. With respect to Hendrik, I grant you that I just used him for the conjunction in the title, the co-appearance of two terms. I didn't make anything, and I wouldn't make anything of that. You're quite right. And you're of course certainly right that hermeneutics as a cultural use of literature didn't play a conspicuous role everywhere. It was a kind of methodological guide for the philologische Wissenschaften. On the other hand, when you said now, in your remarks, that with this, let's say, technical, grammatical, linguistic, methodical, methodological hermeneutics, there was no cultural contextualization, there I would definitely disagree. There is no explicit cultural contextualization, but of course, the methods of hermeneutics, the philologische Wissenschaften, are grounded in a cultural understanding of the texts they are dealing with, even if they don't talk about them. That's, I think, still to be taken for granted. And that's important for me, that point, that, whether they talk about it or not, it's there.

Birus : That was only a misunderstanding of what I have said. It was in the grammatical interpretation, where there is no regard of culture, context, and so on. In the other branch there is, in principle, no regard to the linguistic. And in Schleiermacher's opinion, all interpretation has to oscillate between both sides.

Iser : Comparison and divination arose out of the editing practice of the early nineteenth century. This is the cultural context to which these operations relate and are derived from.

Krieger : One question for information. In order to have a grammatical interpretation that, as you say, captures the meaning of the language of its time, aren't there terms, phrases, concepts in the language of its time that require immediate contextual illumination in order for us to understand what the words are? 
Birus : In the consequences, both coincide.

Krieger : Yes, okay, okay.

Pfeiffer : If one could show that the hermeneutics after Schleiermacher, lets say, from Dilthey onwards, I would say, is not really centering implicitly or explicitly on literature, then my thesis would be wrong. But I still do detect that emphasis in Dilthey, and in Gadamer too, by the way.

Birus : Yes, I completely agree.

Krieger : Okay.

Pfeiffer : And I also agree with the weakness of Gadamer as a theoretician. I said so in twenty pages of my dissertation.

Miller : I've so much to say that I'll have to be very short. One of the things I'd hoped would happen at this conference has certainly happened, perhaps more actively today than before, and that is my understanding of the radical differences between the German and the American and British university traditions. And I might try to say a word about that following a bit from what Hazard said and what Bill Readings said. Picking up on a sentence at the beginning of your paper, where you say that Geisteswissenschaften starts out as Geisteswissenschaft, singular...a pneumatology. And you say that in the middle of the nineteenth century, Geisteswissenschaft and pneumatology were still almost synonymous terms. I've tried to think if there's anything in the United States that's at all parallel to that, and there are three things. One of them is the program at the University of California at Santa Cruz called the History of Consciousness. The second one is the Johns Hopkins methodology called History of Ideas, with Arthur Lovejoy, and George Boas, and many other scholars there.

Krieger : But isn't that originally supposed to be a kind of Begriffsgeschichte. Certainly that's what it was in Lovejoy.

Miller : And the third would be the so-called criticism of consciousness, as I learned it from my colleague Georges Poulet. That made me think of the question whether any of these people that you're all talking about had had any role in the United States at all. Dilthey, yes, in two ways. I learned about Dilthey from Georges Poulet, who thought Dilthey was wonderful. Dilthey is one of the 
origins of his kind of criticism, a criticism which presupposed that, in a way, you could bypass language or go through language to identify yourself with the consciousness of the author. He spoke especially of Dilthey's essay on Novalis, so that this would support what you were saying about there being some emphasis on literature in Dilthey. Dilthey was also very important for Roy Harvey Pearce, one of the disciples of Lovejoy, who brought into California, San Diego, the history of ideas. He couldn't read German. He read Spanish. He read Dilthey, you'd be interested to know, in the Spanish translation. There was a complete Spanish translation, and that itself would have a cultural importance. In Spain in the... it must have been the 'twenties or 'thirties, they cared enough about Dilthey to translate him completely into Spanish.

Krieger : As a matter of fact, it was Americo Castro whom Pearce brought to San Diego, who was Pearce teacher in this.

Miller : Gadamer? Translated, of course, in this country, but important in any crucial way? Only as an influence on E. Donald Hirsch...

Krieger : Negatively.

Miller : Hirsch wanted to use Gadamer to prove that you can identify the intention of the author, and therefore, the meaning of a poem, without equivocation. His later direction seems to us very conservative, where he wants to be able to say, everybody ought to know the following things, and so on, prescribe a kind of national list of things to know.

Krieger : He uses Gadamer negatively. That is, he builds a system by attacking Gadamer, and by reinstituting Boeckh, of all people. Then he gets Boeckh backwards.

Miller : For the most part (and this is the final point I want to make)... to try to mediate between Bill's idea of the university and what was said about the American university being funded by the military-industrial complex: that's absolutely true, and we shouldn't forget that. Most of our salaries at either a private or a public university in this country are paid for either by the government or by rich private people.

Yu : We wouldn't have area studies without the national defense education.

Miller : Right, that's right. 
Adams : A lot of that support is tacitly recognized as not for purposes of national defense.

Krieger : During the Vietnam War, the student left insisted that people like us do the things we do in order to keep sufficiently confused and complicated the minds of those who might be the most radically active students in order to keep them from doing the things they might do to prevent the war from continuing.

Miller : The separation of church and state, which is crucially important for us, and therefore makes us different from England (and I think Bill's right about that), gives us a university which is, in a much more direct way, in the service of the military side of the federal government. What is the role of the humanities in such a university? I think it's very specific to our country. I think Bill is right: Matthew Arnold is crucial. I've been telling anecdotes. Matthew Arnold came to Oberlin College in Ohio, to a small liberal arts college. Arnold visited Oberlin and stayed in the president's house there. Oberlin was, even when I was there in the 'forties, dry you couldn't drink in the town. Arnold was asked by the wife of the president, "What would you like? Can I bring you anything?" And he said, "Whiskey, please." And after about an hour, the maid appeared with a tray and a spoon and a bottle of whiskey. It was assumed that it must be medicinal. That may be an allegory of what happened to Matthew Arnold in this country, but...

Adams : Isn't that a hangover, though, from Oberlin's early religious connections?

Yu : Temperance.

Miller : You could drink 3.2 beer when I was there. Not much chance for hangover. The point that I want to make is that the humanities, in either private universities like Yale or in public ones like the University of California, have a very specific purpose, namely, to teach people how to write, to count, to prepare them for their responsibilities in a technological world. Yale, a little different. It's to give a certain rudimentary humanities education to people who are going to be lawyers, corporation CEO's, high level CIA officers, admirals, people in government, and so on. George Bush is a Yale graduate. When the CIA was exposed, many of the CIA middle-level people turned out to be Yale graduates. That's why the humanities matter at Yale, why there's a big quarrel about this, because as soon as you start fooling around with that function, people get excited. 
That was what was going on in the rebellion against theory at Yale that took place soon after I left, when a new dean came in and tried to reduce the strenght of theory there. Why did he do that? Because the humanities have a very important role in our culture, a role that theory threatened, so he thought. But it sounds to me like a role very different from the German one, and different again from the English.

Krieger : But there's one other role it has. Many years ago, at the University of Illinois, we tried to find out how we could get more English majors, and I was part of a committee that went around to major corporations to find out under what conditions they would be interested in what kind of majors. And we discovered that the English majors were people they wanted very much to have, even for technical jobs. They said, we'd much rather teach them the technical stuff here. What we want you people to do is to make them really exciting participants at a cocktail party. Speak of the trivialization of the humanities. They wanted, in effect, for us to give them enough quotations from Wallace Stevens or somebody so they could, at a cocktail party, be very impressive.

Readings : There you have the tripartite structure, since Hazard accused me of just plain madness, I want to say no, my madness is more complex.

Adams : No, I didn't accuse you. I was not talking about madness at all. I was just saying that in these circumstances, it's madness to think that the American university is based on some ideal of liberal education or criticism, Arnoldian or otherwise.

Readings : It's tripartite though. I mean, you have the research university on the model of Johns Hopkins, you have the liberal arts college, which seems to me different, and then you have the land grant university. And I agree with you that that's where the money comes from, and it's a much more heterogeneous system internally in the States, but the fact is that the notion of rhetoric, writing, liberal education out of the liberal arts college, has to do with this problem of citizenship in the States. And I think Gerry Graff is very good on the fact that, you know, literary culture - - its links to schools of citizenship, to the development of rhetoric as a discipline - is complex. And the only other thing I'd like to say is, I just talked to a whole bunch of physicists who are terrified now because they have been taking all this federal defense money, and suddenly this collider is 
kaput. They are more afraid of the argument from practical utility than we are.

Adams : That may well be true, but if you try to transfer money from any science budget into the humanities in a situation of scarcity in an institution of higher learning, you'll find out how quickly the physicists will abandon that position.

Krieger : Besides which, the physicists are not now well off. The reason they're scared is because they're theoretical. The fact is, the engineering schools are flourishing more than ever because they are the ones who are getting the money, because they are the ones who are getting practical results.

Readings : But the Engineering School is not part of the Faculty of Arts and Sciences usually.

Krieger : No, of course not. But I'm saying, but the physicists really have no direct relation to the national defense necessarily, since their minds are too much in the skies. They're not being "applied" enough. I'm sorry. We've delayed a long time for Ching-hsien.

Wang : I'd like to offer a more encouraging story.

Krieger : He raised his hand when we were talking about creative writers.

Wang : Yes, there, and also an immediate addition to what Hillis mentioned, the national defense and humanities and so on. Actually, in the end of the nineteenth century and early twentieth century, after being defeated by many European nations, China started thinking of learning foreign languages, like English, or French, or German. So they sent students to Germany and everywhere, in order to learn build weapons to fight back. However, after they exposed to those languages many of the students turned to Goethe and Shakespeare, and so on. These talented people, you know, after they studied European and English poetry for one year, they wouldn't think too much about weapons. So that's something that I wouldn't worry too much about. And since this is an international conference on humanistic discourses, I feel obliged to offer some perspective from the Chinese side in order to make it more international. And I believe this is probably the first attempt we have done really in so many years, decades. I also sense that literature scholars in the past, people who could write about literature in the Chinese tradition, would always make some poems. They would be poets. There is no 
doubt about that. But they don't do it anymore. This is really something... it parallels here, and...

Krieger : Is it just parallel, or is it partly Western influence?

Wang : I think it's probably just parallel. Somehow the concept about the completion of the gentleman, man of letters, is different from what it was in the past. So at least in the past, poet would write about literary theory and criticism in the prefaces and epilogues, to his books of poetry, in his letters to friends. We can collect them, and we can say, that these are the literary theory of soand-so, a poet. Many people have done that. But today, somehow this tradition is gone. This is just an echo to what Hazard mentioned earlier.

I'd like to mention another thing. I know a man, a Sinologist, a scholar of Chinese poetry, who once complained to me and said that most of the scholars in China, Hong Kong and Taiwan try to make Chinese poetry sound like nineteenth century English poetry when they translate it into English. And I said, that's too bad. But then I complained to him, and I said that there's another problem. All the Sinologists in the United States, when they translate Chinese poetry into English, compete to create a kind of poetry that's what I call the Sinological poetry. So, Li Po and Tu Fu are all the same. Everybody is just like that. And this shows the urgency, the serious problem about scholars and their exposure to good poetry. However, I do know another man, a Sinologist too, who, after we talked about it, when he flies to places for conferences, would bring his Pope or Dryden to read on the way. I see that his translation of China poetry is more interesting than other's.

I would like to offer one more thing here. Literature is good literature because of its complexity - - we talked about that the other day. It was not the abundance of information, or items, or ideas, in a given work, but rather the strategy you use to contain them that a piece of work artistically complex. That is what I think complexity is. You can say it's simplicity, but it's also complexity. And then that connects to Hillis' idea of Wordsworth's short poem which we can interpret ten times, twenty times. Brevity does not necessarily preclude a poem's complexity. That's the only way you can study fine poetry with rigor and confidence, and to say that we can compare a short lyric with Paradise Lost, or something like that. And in connection with this is the privileged text thing. I see this as our immediate task to make a work, such a Paradise Lost, contain some 
Chinese scholars and their interpretations and a short Chinese poem contain Western scholars without Sinological training.

Krieger : That's a problem. I think that I have a minute or two just to close us up today, although I think Chinghsien has given us the menu and our agenda for the future. I'm just going to take my one minute to put Bill Readings' problems back on the table, without giving him a chance to take it up until next time. But just one question, and that is, the claim, "Literature does not precede the nation state, but follows from it," is the very claim that obviously requires an historical authentication. Therefore there is here an appeal to historical justification as guiding the future, because it claims also, as I remember it, that the decentralization of the nation-state today should put literature and humanistic discourses outside the domain of nations, and perhaps create a new discourse. If we're that much the victims of history, then I get very much concerned with where history's taking us. I'm very concerned, because when I read my newspapers, hear my news reports, and so on, I have a great deal of difficulty in believing anything about the decentralization of the nation-state. Everywhere I look, everywhere I read, everywhere I hear them counting the bodies, I find an accentuation of ethnic nationalism, the emphasis, even in this country, on difference, on racial difference, gender difference, the insistence on the multiplicity of our cultures and of our discourses. All these things don't decentralize the nationstate so much as they create a Balkanization of nationstates within what we used to think of as nations. The whole world has become Yugoslavia, someone said to me the other day, and to the extent that might be the case, that may be where history's taking us. I'm not arguing against what Bill might like the humanities to become. I argue only against the fear that if history leads us, we might not like the way history's going.

Readings : Well, but just one thing there quickly, a fact. Fifty-seven of the world's largest one hundred entities are not nation-states, economically speaking, and I think that's what I'm talking about. I agree with you about Yugoslavia, except that I'd say we simultaneously seek global fusion and local fission. There's no longer an instance that holds them together.

Miller : I think that what you said is what he meant, that is to say, the nation-state is transformed precisely into a heterogeneity.

Krieger : Except you'd have a lot of different nations. 
Yu : How do we define "nations" then?

Krieger : Yes, how do we define a "nation"? You'll have nations within nations. You have, within this country, individual cultures claiming they want to be separate nations, with separate national literatures, by the way. Literature goes with that. I was in India for three years watching and hearing seventeen different national cultures defining themselves by their languages and insisting, each of them on its own literature. How many times I heard a Tamil saying, the Tamil language is so much greater and so much more distinguished in its literature than this or that form of Hindi?

Miller : That's the point. But that's different from the American tradition, which is to make everybody speak English.

Accueil Surfaces | Table des matières | Recherche Surfaces Home Page | Table of Contents | Search

PUM | Livres | Revues | Publications électroniques | Vente et distribution 